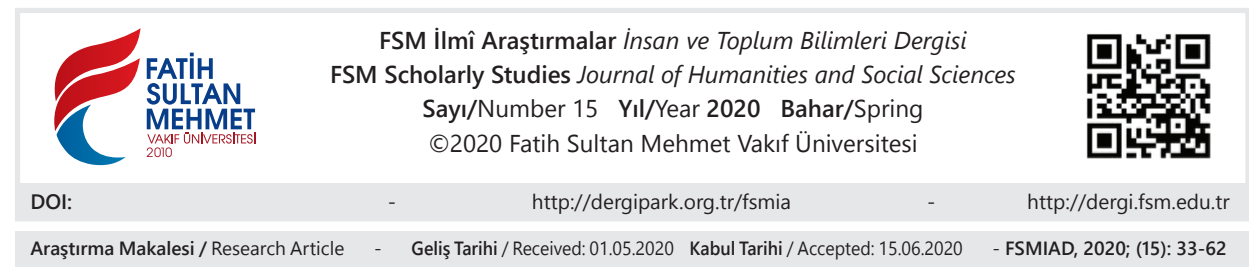

\title{
Osmanlı Döneminde İstanbul'da Modern Bir Mezbaha Kurma Teşebbüsü
}

Engin Çağman*

\section{Öz}

19. yüzyılın sonlarında İstanbul'da bilimsel ve modern usullere göre faaliyet gösterecek bir mezbaha ihtiyacı had safhaya ulaşmış ve bu ihtiyaç birçok kurum tarafından dile getirilmiştir. Şehrin muhtelif yerlerinde mezbahalar bulunmasına rağmen sıhhi ve bilimsel kurallara riayet edilmemesi, kesim öncesi hayvanların ve sonrasında da etlerin kontrollerinin yeterince yapılamaması halkın sağlı̆̆ını tehdit etmekteydi. Öte yandan mezbahaların tam olarak gereğince vergilendirilememesi nedeniyle devletin gelir kaybı da söz konusuydu. Bunun yanı sıra Şehremaneti tarafindan mevcut haliyle mezbahaların ve hayvan satış mahallerinin ihtikâra, dolayısıyla et fiyatının makul bir sebep olmaksızın ciddi şekilde artmasına neden olduğu iddia ediliyordu.

Şehremaneti, mezbahaların sslah edilmesinin çok zor olduğu düşüncesiyle tüm İstanbul halkına hitap edecek sıhhi, bilimsel ve modern özellikleri içeren umûmi bir mezbaha ve hayvan pazarının kurulması amacıyla 1911 yılında bir proje ihalesi açmıştır. İhtiyaçları karşılayabilecek en uygun projeyi belirleyebilmek amacıyla bir komisyon teşkil edilmiş ve kazanan proje sahibine müesseseyi kurması karşılığında işletmesi için kırk yıllığına imtiyaz tahsis edilmesi, bununla birlikte mezbaha ve hayvan pazarı gelirlerinden Şehremanetine de belirli bir pay ayrılması kararlaştııılmıştır.

* Dr. Öğr. Üyesi, Bandırma Onyedi Eylül Üniversitesi İIBF İktisat Tarihi, Balıkesir/Türkiye, ecagman@bandirma.edu.tr, orcid.org/0000-0002-4733-8418 
Makale, Osmanlı arşiv belgeleri üzerinden söz konusu mezbaha ve hayvan pazarı tesisi kurma çabalarını ele almaktadır. Böyle bir tesis ihtiyacının ortaya çıkış nedenleri, ihaleyle ilgili hazırlanan raporlar, ihaleye karşı gösterilen tepkiler, devlet kurumlarının ve sektör temsilcilerinin meseleye yaklaşımı birinci el kaynaklardan faydalanarak ortaya koyulmaya çalışılmıştır.

Anahtar Kelimeler: İstanbul, Şehremaneti, mezbaha, selhâne, hayvan pazarı.

\title{
An Attempt to Establish a Modern Slaughterhouse in Istanbul During the Ottoman Period
}

\begin{abstract}
In Istanbul, the need for a slaughterhouse operating under scientific and modern methods reached its peak toward the end of the $19^{\text {th }}$ century, leading numerous institutions to address such demand. Although there were already established slaughterhouses in various locations of the city at the time, the public health was in jeopardy as medical and scientific principles were not followed, and no pre or post-slaughter inspections of animals were carried out. Moreover, these slaughterhouses were not subject to appropriate taxes, resulting in government revenue loss. Furthermore, the "Şehremaneti" (Municipality) claimed that the slaughterhouses and livestock markets in their current form were generating unfair profits, causing the meat prices to spike without any precedence.

Considering the reformation of current slaughterhouses a grueling task, the Şehremaneti launched a tender in 1911 for the construction of a public slaughterhouse and livestock market equipped with all the medical, scientific, and modern standards for use of all the inhabitants of Istanbul. A commission was appointed to determine the most suitable project and it was decided to grant the operating rights of the establishment for 40 years to the winning project in return for the construction of such establishment, as well as to allocate a certain share to the Şehremaneti from the revenues of the slaughterhouse and the livestock market.

The present paper examines the efforts undertaken to build a slaughterhouse and a livestock market using Ottoman archival documents. The causes of the demand for such an establishment, the reports on the tender process, the reactions against the tender, and government institutions and industry leaders' approach on the issue were identified through first-hand sources.
\end{abstract}

Keywords: Istanbul, Şehremaneti, slaughterhouse, abattoir, livestock market. 


\section{Giriş}

İstanbul'un temel gida maddelerinden olan etin tedariki konusunda Osmanlı Devleti yöneticileri çok hassas davrandıkları gibi ilgili tüm birimlerden aynı hassasiyeti göstermeleri istenirdi. Saray, ordu ve halkın yaygın tüketimi olan koyun ve kuzu etinin temini için yapılan resmi yazışmalarda bu hususun özellikle vurgulandığ 1 görülmektedir. ${ }^{1}$ Osmanlı döneminde çok yoğun bir nüfusa sahip olan İstanbul'un" birçok temel malda olduğu gibi et ihtiyacı da şehir dışından karşılanmaktaydı. Bazı Rumeli şehirlerinin yanı sıra İç Anadolu, Doğu Anadolu, Ege ve Karadeniz, gibi Anadolu'nun çok çeşitli bölgelerinden celepler vasıtasıyla koyun nakledilirdi. $^{2}$

İstanbul'a getirilen hayvanların kesimiyle birlikte etlerinin, derisinin ve sakatatının ilgili esnafa dağıtımı selhânelerde icra edilirdi. Osmanlı Devleti zamanında İstanbul'da ilk selhâneler fetihten sonra Fatih Sultan Mehmed tarafından Yedikule surlarının dışındaki bölgeye yaptırılmış, nüfusun artmasına bağlı olarak yeni selhâneler kurulmuştur. On altıncı yüzyılın ortalarına doğru Haliç ve Marmara'da bulunan sur kapılarının dışında yeni selhâneler inşa edildikten sonra Galata, Kasımpaşa, Tophane, Beşiktaş, Boğaziçi ve Üsküdar'a doğru yaygınlaşmıştır. Selhânelerin bir kısmı esnafa ait olduğu gibi miri statüde selhâneler de mevcuttu. ${ }^{3}$

19. yüzyılın sonlarında bazı nedenlerden dolayı mezbahaların 1slah edilmesi gündeme gelmiştir. Bu yöndeki çabalar Avrupa ile hemen hemen aynı dönemde başlamasına rağmen Osmanlıda farklı bir süreç takip etmiş, mezbahalar endüstriyel bir kesimevi tarzına dönüşmemiştir. Bu konudaki sslahat projelerinin Avrupa'yla benzeşen tarafi et kesimini, hayvansal atığı ve kesimle ilgili süreçleri şehrin dışına çıkarmayı hedeflemesidir. Fakat maddi imkânsızlıklar nedeniyle bu konuda

1 Muharrem Öztel, "Tanzimat Dönemi ve Sonrasında İstanbul Et Piyasasını Düzenlemek İçin Alınan Tedbirler”, History Studies, volume 5, issue 5, Eylül/September 2013, s. 149-150; Halime Doğru, "Rumeli'de Celepkeşanlar",http://docs.neu.edu.tr/library/nadir_eserler_el_yazmalari/Dergiler/1_Belletenler/1502.pdf, Erişim tarihi 14.04.2020, s. 12.

1916 yılında İstanbul Vilâyeti Ziraat Müdüriyetinin, şehrin temel gıda maddelerinin karşılanmasıyla ilgili hazırladığı bir raporda nüfusun bir buçuk milyona yaklaştığı ifade edilmektedir. BOA, DH.UMVM.83/26 Lef 1, 9 Ağustos 1332 (22 Ağustos 1916). Fakat muhtemelen bu rakam biraz mübalağalıdır. İstanbul'un nüfusu 1916-1917'de (1335) 1.129.655 idi. Öztel, a.e., s. 150.

2 Ahmet Tabakoğlu, “Osmanlı Döneminde İstanbul'un İaşesi”, http://openaccess.29mayis.edu. tr:8080/xmlui/bitstream/handle/29mayis/1519/AHMET\%20TABAKO\%c4\%9eLU.pdf?sequence $=1 \&$ isAllowed=y, Erişim tarihi 14.04.2020, s. 126; BOA, ŞD.851/22/17 Lef 5, 28 Mayıs 1330 (10 Haziran 1914).

3 Ahmet Uzun, İstanbul'un İaşesinde Devletin Rolü: Ondalık Ağnam Uygulaması 1783-1857, Ankara, Türk Tarih Kurumu Yayınları, 2006, s. 132-133. 
ciddi bir başarı gösterildiği söylenemez. 1877 tarihli Dersaadet Belediye Kanunu ve yine aynı yılda çıkarılan Vilâyet Belediye Kanunu, mezbahaların ıslahıyla ilgili önemli değişiklikler içeriyordu. Buna göre uygun yerlere mezbahalar inşa edilmesi kararlaştırılıyor, şehir içinde hayvan kesimi yasaklanıyor ve umûmi mezbahalar açılana kadar mevcutların dışında yenilerinin inşasına izin verilmiyordu. ${ }^{4}$

II. Abdülhamid döneminde mevcut selhânelerin kaldırılarak yerine modern ve umûmi bir mezbaha kurulması hususunda bazı proje ve teklifler sunulmuş ve yoğun çabalar sarf edilmişse de netice alınamamıştır. Bununla beraber aynı doğrultudaki teşebbüsler II. Meşrutiyet dönemi ve sonrasında da devam etmiştir. ${ }^{5}$

Çalışma, İstanbul'un ihtiyacını karşılamak için 1911 yılında Şehremaneti tarafindan, umûmi, fenni ve modern bir mezbaha kurulması amaciyla düzenlenen bir proje ihalesini ele almaktadır. Uzun ve yorucu bir süreç olmasına ve ihalenin neticesiz kalmasına rağmen hem devletin, hem de proje sahipleri ve ilgililerin konuya yaklaşımları, beklentileri ve yaşanan problemler birincil kaynaklar vasıtasıyla ortaya koyulmaya çalışılmıştır.

\section{1. İstanbul'da Modern Bir Mezbaha İhtiyacı}

1891 yılında Mehmed Naili imzasıyla doğrudan padişaha gönderilen bir layihada, İstanbul'da selhânelerin yetersiz olmasından kaynaklanan problemler arz edilmiştir. Mehmed Naili Efendi ilk olarak, kasap dükkânlarında kesilen hayvan kanlarının kokusundan dolayı mahalden geçmenin mümkün olmadığını, havayı bozarak birçok hastalığa neden olan hayvan kesimlerinin selhânelerde yapılması halinde ahalinin korunacağını ifade etmiştir.

Layihada ikinci olarak, kesilen hayvanın üflenip şişirilmeden derisi yüzülemeyeceği ve üfleyen kişinin nefesi ete de geçeceği için bu işlemi yapanların sağlıklı olmaması halinde hastalıklarının eti yiyenlere de bulaşarak yayılmasının kaçınılmaz olacağına dikkat çekilmiştir. Mehmed Naili Bey’e göre hali hazırda mevcut kasaplar muayene edilirse çoğunun hastalıklı olduğu görülecektir. Selhâneler kurulduğunda kesim yapacak kişiler öncelikle doktor muayenesinden geçeceği için hastalıkların yayılmasının önü alınmış olacaktır.

Üçüncü olarak, selhânelerin hizmete girmesiyle birlikte kesilecek hayvanlar damgalanacağından hayvanların cinslerinin bilineceği, tüketicilerin ona göre ödeme yapacağ1 ve muhtekir kasapların verdiği zarardan korunacağ ileri sürülmüsstür.

4 Sinem Burcu Uğur- Seda Tan, “19.Yüzyıl Mezbaha Reformu ve Osmanlı'daki Yansımaları”, MAE Veterinerlik Fakültesi Dergisi, 4 (1), 2019, s. 21-22.

5 Mehmet Aydın, "Mütareke Döneminde İstanbul Basınında Karaağaç Mezbahasına Yönelik Tartışmalar”, Uluslararası Sosyal Araştırmalar Dergisi, volume 3, issue 14, Fall 2010, s. 100. 
Dördüncü ve son olarak, Mehmed Naili Efendi, saltanatın başkenti olan İstanbul'da temizliğin sağlanmasının çok önemli olduğunu vurgular. Ona göre özellikle beldenin her köşesindeki kasap dükkânlarında dikkat çekecek şekilde hayvan kesilmesiyle ortaya çıkan çirkin manzaranın göz önünden kaldırılması birçok fayda sağlayacaktır. ${ }^{6}$

Mehmed Naili Efendi kurulması düşünülen selhânelerle ilgili bir de sözleşme taslağı hazırlamıştır. Sözleşmede, Şehremanetinin tayin edeceği mahallerde sayısı otuzu geçmemek şartıyla ve kârgir olmak üzere selhâneler inşası teklif edilmektedir. Sözleşmeye göre selhânelerin yapılacağı araziler hükümet tarafından bedelsiz olarak verilmeli ve imtiyazın kabul tarihinden itibaren üç ay içinde selhâne mahalleri belirlenmelidir. Şayet bu süre içinde mahaller tayin edilmez ve gereken arazi verilmezse imtiyaz sahibi, uygun göreceği yerlerde kendisi arazi satın alarak selhâne tesis edecektir. Fakat, imtiyaz sahibi, satın aldığı arazi üzerine tesis edeceği inşaatın bedelini, hükümete ödeyeceği bedelden öncelikle kesme salahiyetine sahip olacaktır. İmtiyaz süresinin bitimine kadar selhânelerin hududu dâhilinde yani Rumeli yakasında Çatalca'dan Kavak'a; Anadolu yakasında ise İzmit'ten Kavak'a kadar olan bölgede selhâne haricinde hayvan kesilmeyecektir. Bahsi geçen hudutların dışında kesilerek hudut dâhiline getirilecek hayvanlar en yakın selhâneye naklolunarak baytar tarafindan muayene edildikten sonra damgalanacaktır. Ancak bu işlemlerin akabinde hudut dâhilinde satışına izin verilecek fakat selhâne resmi alınacaktır. Hayvanları kesecek kişilerin hastalıktan korunmalarını sağlamak amacıyla muayeneleri için gereği kadar doktor görevlendirilecek ve toplam maaşları yıllık beş bin lirayı geçmeyecektir.

Selhânede kesilen veya dışarıda kesilerek selhâneye getirilen hayvanların baytarlar tarafindan muayene edilmeden ve damgalanmadan satılmasina izin verilemeyeceğinden yenmesinin sağlığa zararlı olup olmadığı ve ayrıca kesen kişilerin hastalıktan korunmaları hususunda baytar ve doktorlar mesul tutulacaktır. Hudut dâhilindeki selhâne dışında hayvan kesmek veya hudut dışında keserek hudut içinde muayene edilmeksizin hayvan satmak yasaklanacağından buna aykırı davrananlara verilecek cezayı belirlemek için bir nizam hazırlanacaktır. Kimin elinde muayenesiz ve damgasiz et bulunursa derhal alıkonularak muayenesiz hayvan satanlar hakkında yapılacak işlemler onlar için de uygulanacaktır. Usulüne göre selhânelere getirilen hayvanlardan ya da etlerden haklarında ruhsat verilmeyenler için yapılacak işlemlere dair de bir nizam ihdas edilecektir. İmtiyaz sahibinin istediği şekilde bir Osmanlı şirketi kurmaya hak ve salahiyeti olacaktır. 
İhraç edilecek hisse senedi ile tahviller damga resminden muaf tutulacak ve selhâne memurlarının tamamı Osmanlı tebaasından seçilecektir.

Sözleşme taslağında ifade edilen hususlardan biri de selhâneye getirilecek hayvanlar için cinslerine göre alınacak vergilerdir. Buna göre koyun ve keçi cinsinden beşer kuruş, yerli sığır cinsinden on beş, ecnebi sığır cinsinden yirmi ve domuzdan on kuruş alınması yönünde bir tarife belirlenmiştir. Ayrıca domuzlar için yapılacak selhânenin isteğe bağlı olmasının sözleşmede belirtilmesi talep edilmektedir. Mehmed Naili Efendi'nin hazırladığı sözleşme taslağ 1 gelirlerden hükümete senelik yirmi bin lira verilmesi, imtiyazın kırk senelik olması ve sürenin bitiminde selhânelerin bilâ bedel hükümete terk ve teslim edilmesi önerisiyle sona ermektedir. ${ }^{7}$

Mehmed Naili Efendi'nin layiha ve sözleşme taslağını arz etmesinin üzerinden uzun zaman geçtikten sonra konunun tekrar gündeme gelmesi, İstanbul'da sıhhi şartları haiz ve ihtiyaçları karşılayacak selhâneler yapılması konusunda önemli bir gelişme kaydedilmediğini göstermektedir. Sadaretten Dâhiliye Nezaretine 22 Ocak 1905 tarihinde gönderilen bir belgeye göre, hayvanların kesilmesinden önce muayenesine ve mezbahalarla etlerin kontrol ve muhafazasina dair bir tıbbi komisyon tarafindan layiha hazırlanarak uygulanmasının müzakeresi için Meclis-i Vükelâya havale edilmiştir. Meclis söz konusu layiha üzerinde ça1ışmış, fakat bu husustaki görüşlerinin alınması amacıyla Şehremanetinden bilgi istenmesine karar verilmiştir. ${ }^{8}$

Konuyla ilgili olarak Şehremanetinin yaptığ 1 açıklamalar 27 Mart 1905 tarihinde Dâhiliye Nezareti tarafından Sadarete aktarılmıştır. Buna göre Şehremaneti, İstanbul'a gelen hayvanların yürürlükte olan talimat gereğince İstanbul ile Küçükçekmece arasındaki mahallerde ve şehrin girişlerinde fenni tedbirler uygulandığını ifade etmiştir. Bu bağlamda Fatih ve Tophane mezbahalarında kesilen hayvanların etlerinin, söz konusu mezbahalarda bulundurulan baytarlar tarafindan muayeneden geçirilerek hastalık emareleri görülen etlerin tüketilmemesine dikkat ve itina gösterildiği belirtilmiştir. Şehremaneti ayrıca bahsi geçen layihanın incelendiğini ve layihada belirtilen şartların ve fenni uygulamaların çoğunun mevcut nizam ve kararlara göre kendilerine bağlı baytarlar tarafından yürütüldüğünü beyan etmiştir. Ancak buna rağmen muayenelerin tam anlamıla ifası ve satılan etlerin sıhhatinin korunmasının uygun yerlerde umumi selhânelerin kurulmasına bağlı olduğunu ileri sürmüştür. Yine Şehremanetinin ifadesine göre umûmi selhânelerin yokluğu nedeniy-

7 BOA. Y.PRK.AZJ.19/42/1 Lef 1, 3 Haziran 1307 (15 Haziran 1891).

8 BOA, DH.MKT.926/57/1 Lef 1, 9 Kanun-1 sani 1320 ( 22 Ocak 1905). 
le birçok esnaf fırsat buldukça bazı gizli ve ücra yerlerde hayvan kestiği için hıfzıssıhha kurallarına aykırı durumlar ortaya çıkmaktadır. Bu gibi olumsuzlukların tamamen önüne geçmenin pek mümkün olmadığına inanan Şehremaneti, konuyla ilgili layiha ve talimatın fenni muhtevasının çeşitli kurumlarda görevli baytarlardan teşkil edilecek bir komisyon tarafindan incelenmesinin gerekliliğini bildirmiştir. ${ }^{9}$

\section{Mezbaha Yapımının İhale Edilmesi ve Sunulan Projeler}

İstanbul'da umumi bir mezbaha ve hayvan pazarı ihtiyacını karşılamak için 1911 yılında* ihale açılmasına rağmen proje sürüncemede kalmıştır. 1914 yılında, İstanbul Vilâyeti Meclis-i Umûmisi Nafia Encümeninin ${ }^{* *}$ ve ihaleye katılan projelerin değerlendirilmesi için kurulan komisyonun raporlarını ve ihalenin sonuçlarını içeren bir layiha hazırlanmıştır. Layiha, hem o dönemde modern ve sıhhi bir mezbahada bulunması gereken özelliklerle, hem de proje safhalarıyla ilgili çok geniş ve zengin bilgiler içermektedir.

Layihadan edinilen bilgiye göre Şehremaneti, İstanbul'da umûmi bir selhâne ve hayvan pazarı tesisi konusunda Bâb-1 Âli ile yazışmalarda bulunmuş, bu konuda kendilerine verilen dilekçeler ve haritalar Belediye Cemiyet-i Umûmisi tarafından incelenmiş; hiçbir sıhhi muayeneye ve baytar kontrolüne tabi tutulmadan birçok yerde icra edilen hayvan kesiminin kontrol altına alınması ve umûmi sıhhatin temin edilmesinin zaruri olduğu belirtilmiştir. Bu nedenle söz konusu problemleri giderebilmek amaciyla Belediye Cemiyet-i Umûmisinin bir müsaba-

9 BOA, DH.MKT.926/57/5 Lef 2, 14 Mart 1321 (27 Mart 1905).

* Mezbaha ve hayvan pazarı için ihaleye çıkılış tarihi maalesef konuyla ilgili faydalandığımız belgelerden tam olarak tespit edilememiş̧ir. Fakat yazışmalardan anlaşıldığına göre 1911 yılı başlarında gerçekleşmiş olması kuvvetle muhtemeldir.

** "Vilâyet Encümenliği, Vilâyet genel idaresinin karar organlarından biridir.1913 Vilâyet Muvakkat Kanunu'na göre kurul, Vilâyet Umûmi Meclisinin her toplantı yılı sonunda kendi üyeleri arasından seçtiği dört üyeden oluşmaktadır. Başkanı, vali veya onun tayin edeceği bir kişidir. Kanunun 144. maddesine göre vilâyet encümeninin bazı görevleri şunlardır: Vilâyet bütçesi hakkında görüşünü bildirmek, vali tarafından gönderilen harcama cetvellerinin bütçeye uygun olup olmadıklarını incelemek, mahalli hizmetlere ilişkin Vilâyet Umûmi Meclisine gönderilecek projeler hakkında düşüncesini sunmak, ilk toplantıda meclise sunmak şartıyla acil hallerde Vilâyet Umûmi Meclisinin görev alanına giren konularda karar almak ve valinin istediği her konu hakkında mütalaa vermek.", Seral Tuncer, "II. Meşrutiyet Döneminde Bir İdari Reform: 1913 İdare-i Umûmiye-i Vilâyat Kanun-1 Muvakkatı”, http://cdn.istanbul.edu.tr/FileHandler2. ashx?f=ii.-mesrutiyet-doneminde-bir-idari-reform-1913-idare-i-umumiye-i-vil\%C3\%A2y\%C3\%A2t-kanun-i-muvakkati_seral-tuncer.pdf, Erişim tarihi, 29.05.2020, s. 593. 
ka düzenlediği ifade edilmiştir. ${ }^{10}$ Müsabakaya aşağıda isimleri belirtilen kişi ve kurumlar katılmıştır:

A-Fransa belediyelerinin mezbaha umum şirketi

B-Fökyö ve ortakları

C-Paris Hayvanat Pazarı Rejisi Vekili Breteau

D-Papadopoulo, Jarre ve ortakları

E-Emile Camus

F-Montin Duglassy ${ }^{11}$

Bunlar arasında nihai değerlendirmeye alınan dört projede mezbaha ve hayvan pazarı kurulması için önerilen yerler ise şunlardır:

A-Haliç'in son bulduğu yer

B-Langa Bostanı (Demiryolu ile sahil arası)

C-Kazlıçeşme ile Zeytinburnu arası (Karayolu ile demiryolu güzergâhı civarı)

E-Langa Bostanı (Demiryolunun iki tarafi)

E projesinin seçtiği yerle ilgili konulan şerhte, Şehremaneti başmühendisliğinden verilen rapora göre E projesinin bulunduğu yerin Şehremanetince seçilen mevki olmakla birlikte bu mahallin ilerde yapılacak genişletme için ihtiyaten gösterildiği ve asıl mezbaha ile pazar mahallinin demiryolu hattının üst tarafında düşünüldüğü ifade edilmektedir. ${ }^{12}$

Şehremaneti, süreçten Dâhiliye Nezaretini bilgilendirmiş ve proje ihalesinin sonuçlarını da içeren 17 Eylül 1913 tarihli yazısında yeni bir umumi mezbaha kurulması halinde hayvan pazarlarında et ticaretinin kontrol altına alınarak celeplerin ihtikâr yapmasının engelleneceğini, herhangi bir neden olmadan artış gösteren et fiyatlarının önüne geçileceğini ve belediyenin yıllık elli bin lira civarında gelir elde edeceğini ileri sürmüştür. Ayrıca umûmi selhâne işletmeye açıldığında şehrin birçok yerinde gelişigüzel durumda faaliyet gösteren selhânelerin kapatılarak başka amaçlar için kullanılacağını bildirmiştir. ${ }^{13}$

10 BOA, ŞD.851/22/33 Lef 3, 11 Kanun-1 sani 1329 (24 Ocak 1914).

11 BOA, ŞD.851/22/33 Lef 15, 16 Nisan 1328 (29 Nisan 1912).

12 BOA, ŞD.851/22/33 Lef 35, 16 Nisan 1328 (29 Nisan 1912).

13 BOA, ŞD.851/22/32 Lef 2-3, 4 Eylül 1329 (17 Eylül 1913). 


\section{Teknik Komisyonun Projelere Dair İnceleme Raporu}

Müsabaka ilanından sonra, katılanların verdiği planlar, teşkil edilen fenni bir komisyon tarafından incelenerek imtiyaza hak kazanan proje ilan edilmiştir. Komisyon, görüşlerini beyan etmeden önce, yapılacak olan selhânelere ait binaların ve bölümlerinin tertibat ve tefrişatının dönemin teknolojik gelişmelerine uygunluğuna dair bilgilerini artırmak amaciyla Almanya ve Fransa' daki uzmanların yayınlarını incelemiştir. ${ }^{14}$ Önce modern bir mezbahada bulunması gereken özellikler ve tahsisi zorunlu olan mekânlarla ilgili ayrıntılı bir rapor hazırlayan komisyon özetle aşağıdaki sonuçlara ulaşmıştır:

Kara ve deniz yoluyla getirilen hayvanlar herhangi bir yere sapmadan doğrudan doğruya tesisin ahırlarına sevk edilmelidir. Hayvanların baytar muayenesinin ve shhi hizmetlerin tam olarak yerine getirilmesi için yeterli kapasitede varış ve baytar muayene parkları kurulmalı, müşahede ve tecrit için iki ayrı ahır yapılmalıdır. Varış parklarındaki ahırlarla sağlıklı hayvanlara tahsis edilen ahırlar birbirinden ayrı olmalıdır. Tesis içindeki yollar, verilen muhtelif hizmetlerle çakışmayacak şekilde ayrı ve müstakil olmalıdır. Hayvan ticareti için mutlaka bir borsa kurulmalı ve pazarla borsa arasında tüccar arabalarının geliş gidişlerine mahsus geniş bir giriş avlusu bırakılmalıdır. Satılacak ve kesilecek hayvanlara bu avluda asla gidiş yeri verilmemelidir. Hayvanlar kendilerine tahsis edilen yerlere adeta bir kanalı takip edercesine gidebilmelidir. Pazarın satış yeri, hayvanların cinslerine göre teşhir edilecek tarzda düzenlenmelidir. Ahırlar kesim salonlarına mümkün olduğu kadar yakın olmalı ve diğer hizmetlerle çakışmayacak şekilde bir yol ile ayrılmış olmalıdır. Küçük ve büyük hayvanların kesimleri farklı veya ortak salonlarda icra edilse bile kendilerine özel tertibata göre ve tamamen ayrı yapılmalıdır. İşkembe ve bağırsakların tahliyesi için ayrılan mahallin alanı, kesim salonları ile tahliye mahalli arasındaki mesafe ve işkembelerin temizlik mahallinin yakınlığı dikkate alınarak hesaplanmalıdır. Atıkların ortadan kaldırılması için özel tertibat yapılmalıdır. Etlerin dışarı çıkarılma işlemleri de bütün hizmetlerden kesinlikle bağımsız olmalı ve ahali ile arabalar kesim salonuna girmemelidir.

Raporda, hayvanların kesimden önce bekletileceği bir salonla kesimden sonra etlerin bozulmadan muhafaza edilmesi için kullanılacak başka bir bölümün inşa edilmesi gerekli görülmüştür. Buna göre, bekleme salonu bir soğuk hava mahzeni özelliğinde ve sıcaklığı 10 derece civarında, etlerin muhafaza edileceği asıl soğuk hava bölümünün ideal sıcaklığı ise 2-5 derece arasında olmalıdır. Etler ikinci kısımdan ya doğrudan satışa çıkarılacağından veya dağıtımı yapılacağından bu salonlar ortalama 4-5 günlük etin saklanabileceği büyüklükte yapılmalıdır. 
Daha sonra komisyon, belirli hizmetlerin yerine getirilmesi için ihtiyaç duyulan mekânları sıralamıştır. Bu kapsamda yönetim binası ve yeri, tıbbi muayene mahalleri, iki lokanta mahalli, vestiyer, hamam, duş ve tuvaletler, polis merkezi ve itfaiye heyeti için özel mahaller, münferit bir mevkide ot ve yem ambarları, özel çıkış yerleri olan gübre mahalleri, kullanılmış suların tasfiyesi için makine dairesi mahalleri, temizlik için gereken su tevziatı ile tartı ve kontrol dairelerinin yapımı veya tahsis edilmesi istenmiştir. ${ }^{15}$

Komisyon, kurulacak olan mezbahanın kapasitesini ve her türlü hayvan için günlük kesim miktarını tespit edebilmek amacıyla İstanbul'da yıllık kesilen hayvan sayısını göz önüne almıştır. ${ }^{16}$ Konuyla ilgili incelemelerin ayrıntılı bir şekilde ifade edilmesinden sonra, ihaleye katılan projelerin değerlendirmesine geçilmiş ve projelerin her biri bir harfle tanımlanmıştır. Buna göre ihaleye altı proje katılmış olup A, B, C, D, E ve F harfleriyle isimlendirilmiştir. Komisyon, ayrı ayrı ele aldığ 1 her projenin olumlu ve olumsuz yanlarını belirtmiştir. 29 Nisan 1912 tarihli raporun netice bölümünde projelere dair yaptıkları değerlendirmelerin özetini veren altı kişilik komisyonun üyeleri şu isimlerden oluşmaktadır:

1-Komisyon Reisi Nafia Nezareti Fen Müşaviri Frekyan

2-Nafia İdaresi Ser Mühendisi Mühendis Mektebi Muallimlerinden Feyzi

3-Evkaf Nezareti Tamirat Müdür Muavini Mühendis Mektebi Muallimlerinden Ali Talat

\section{4-Askeri Baytar Mektebi Müdür ve Muallimi Binbaşı M. Nuri}

\section{5-Şehremaneti Ser Mühendisi Auric}

6-Tıp Fakültesi Hıfzıssıhha Muallimi Meclis-i Tıbbiye-i Mülkiye ve Sıhhiye-i Umûmiye Azasından Aristidi

Azalardan ilk dördü E projesini tercih etmiş, komisyonun 5. ve 6. üyeleri Auric ve Aristidi Beyler ise karara katılmadıklarını belirterek E projesinin mevcut haliyle uygun olmadığını bildirmişlerdir. Söz konusu iki üye, E ve C projelerinin

15 BOA, ŞD.851/22/33 Lef 13-14, 16 Nisan 1328 (29 Nisan 1912).

16 Raporda belirtildiğine göre 1909 ve 1910 'da, İstanbul'da kesilen hayvan sayısı, koyun ve keçi 1.130.128, kuzu ve oğlak 114.758 , sığır ve manda 106.524 ve dana 30.598 olmak üzere y1llık olarak toplam 1.382.008' dir. BOA, ŞD.851/22/33 Lef 11. 9 Kanun-1 sani 1329 (22 Ocak 1914). Bu tarihten üç sene sonra "1913 yılında İstanbul'da tüketilen et miktarı 18.1 bin ton (nüfus başına 18 kilo) civarındaydı. Kasaplık hayvan ihtiyacının \% 11i şehir içinden, \%42si Trakya ve Rumeli'den, \%27si Bulgaristan'dan, \%20si de Anadolu'dan karşılanmaktaydı. Savaş öncesinde et sıkıntısı çekilmemekle birlikte et tüketimi savaş öncesi miktarının üçte birine kadar düşmüş, fiyatlar ise 20 kat artmıştır.”, Tabakoğlu, a.e., s. 165. 
birbirlerine göre güçlü ve zayıf yanlarını kıyaslamış; her ne kadar bu iki projeyi diğerlerinden daha iyi bulmuşlarsa da sıhhi, idari ve mali şartları tam olarak karşılamadığını ifade etmişlerdir. Bu olumsuzluklara ilave olarak Şehremanetinin menfaatlerinin de göz önünde bulundurulmasının ve bu iki projenin birleştirilerek yeni bir proje düzenlenmesinin daha uygun olduğunu ileri sürmüşlerdir.

E projesini onaylayan komisyonun dört üyesi, planlarının anlaşılmayacak özelliklerde olduğu ve ayrıca resmi şartlara uymadıkları gerekçesiyle D ve F projelerini değerlendirmeye almamış; bazı üstünlüklerinden dolayı E projesi lehinde karar vermiştir. Komisyona göre E projesinde genel olarak belirtilen alanlar talebe uygun olup ihtiyacı karşılayabilmekte, alanların her biri icra edeceği hizmete elverişli durumda görülmekte, inşaatlar fenni açıdan mükemmellik arz etmektedir. Bunun yanı sıra komisyon, projenin, Avrupa'nın büyük şehirlerinde uygulanan ve bu konuda ihtisas sahibi kişilerin kabul ettiği son sistem olduğunu belirtmiştir. Bu sistemin özelliği, "ileri doğru hareket”, yani hayvanların mezbahaya girmesiyle birlikte karşılaşılan tüm merhalelerin ve hizmetlerin herhangi bir karışıklığa ve karşılaşmaya meydan vermeden et olarak mahallinden çıkarılması esasına göre kurgulanmasıdır. Projenin kabul edilmesindeki diğer nedenler ise müessese hizmetlerinin en önemlisi olarak görülen sihhi hizmetlerle hayvan sağlığının kontrol ve müdahalesinin mükemmelliği, belirlenen vergi tarifesinin uygunluğu, daha önce hesaplanmış olan alan genişliklerine yakınlığ 1 ve talep edilen para ile tahsis ettikleri alan arasında en uyumlu fiyatı vermesidir.

Komisyon, karara itiraz eden iki kişinin itirazlarına konu olan hususları daha önce tafsilatıyla rapor ve tablolarla anlattıklarını, mezbaha işletilmesinden elde edilecek gelirlerin belirlenmesi işinin kendi görevleri olmadığını beyan ederek projeler için 10 üzerinden değerlendirmede bulunmuştur: Buna göre projelere aşağıda belirtildiği şekilde notlar verilmiştir:

Notların kategorileri

9-10: Mükemmel

7-8: Pekiyi

5-6. İyi

3-4: Vasat

1-2: Fena

\section{Projelerin aldığı notlar}

E: 9 (Dokuz)

B: 3.5 (Üçbuçuk)

C: 2.5 (İkibuçuk)

A: $2\left(\right.$ İki) ${ }^{17}$ 


\section{E Projesinin Tadili Talebi ve Proje Sahibi Emile Camus'un Yaklaşımı}

Projeleri değerlendiren komisyondan iki kişinin, E projesinin tadil edilmeden kabulünün İstanbul'un ihtiyacının karşılanması ve Şehremanetinin çıkarlarının korunması açısından uygun olmadığına dair kanaatleri üzerine durum Belediye Cemiyet-i Umûmisine iletilmiş ve burada yapılan müzakereler neticesinde E projesi sahibinden gereken değişiklikleri yapması istenmiştir. ${ }^{18}$ E projesi sahibi Emil Camus, bir iki istisna dışında talepleri yerine getireceğini bildirmiş ve anlaşmazlığa konu olan hususları ele alarak görüşlerini paylaşmıştır.

Tadil konularından biri proje için seçilen yerle ilgilidir. Camus, mekân olarak seçtikleri Langa Bostanı'nın uygun bulunmadığını, fakat Şehremanetinin daha önce Langa Bostanı'nı seçmesi üzerine kendilerinin de planlarını ona göre yaptıklarını, buna rağmen sözleşmede belirttikleri üzere tesisin, Şehremanetinin uygun göreceği herhangi bir mahalde yapılmasını onayladıklarını ifade eder.

Diğer bir husus, Şehremanetinin, sıhhi kontrole ait işlemlerin, hayvanların denizden ve karadan gelmelerine göre iki ayrı mahalde icrasını istemiş olmasıdır. Camus aslında projelerinde bu şekilde tertibat kurulduğunu, inşaattan önce Şehremaneti fenni komisyonunun onayına sunacaklarını, fakat yeterli görülmezse planda istenecek her türlü tadilatı kabule razı olduklarını açıklamıştır.

Camus'un tadilini kabul ettiği maddelerden biri de hayvan muayene mahalliyle ilgilidir. Camus, Şehremanetinin söz konusu mahallin inşasını hayvan pazarı ile selhâne arasında önerdiğini, fakat teknik açıdan hayvanların pazardan çıkınca doğrudan kesim mahalline girmesinin genel kaide olduğunu, buna binaen muayene mahallinin araya yapılmasının uygun olmayacağını vurgulamıştır. Fakat bu talebin genel kaidelere aykırılığına rağmen yine de Şehremaneti tarafından nasıl istenirse ona göre yapılacağını bildirmiştir.

Şehremanetinin tesisten elde edeceği gelirin nasıl ve ne oranda ödeneceği de taraflar arasında anlaşmazlığa konu olmuştur. Camus, gelirin safi hasılat üzerinden \%45'e çıkarılması teklifini reddetmiştir. Aslında daha önce kendilerinin \%50 önerdiklerini, fakat Şehremanetinin, payın safi hasıla yerine hayvan başına verilmesini istediğini ve talebin o zaman kabul edildiğini hatırlatan Camus, son yapılan anlaşma gereğince ödemenin safi hasılat üzerinden değil kararlaştırıldığ gibi hayvan başına yapılacağını, bu durumda et fiyatına göre Şehremanetinin yılda en az otuz bin lira kazanacağını ve tedricen bu rakamın artacağını söylemiştir.

Şehremanetinin taleplerinden biri de daha önce kırk yıl olarak kararlaştırılan imtiyaz süresinin otuz yıla indirilmesidir. Fakat bu teklifi uygun bulmayan 
Camus, en yakın rakibi olan $\mathrm{C}$ projesi ile mukayese yaparak kendi projesinin bu konudaki üstünlüğünü ortaya koymaya çalışmıştır. Projesine göre tesisin maliyeti için on sekiz milyon frank harcanacağını, C projesinin süreyi otuz sene olarak vermesine rağmen maliyetinin 10 milyon frank olduğunu maliyetler üzerinden hesaplayarak $\mathrm{C}$ projesinin imtiyaz süresinin $\mathrm{E}$ projesinden 16 sene daha fazla süreye denk geleceğini ve bu nedenle Şehremanetinin aleyhine olacağını iddia etmiştir. Camus, $C$ projesi vergi tarifesinin de E projesine göre daha yüksek olduğunu, bu nedenle kendilerine göre daha fazla para kazanacağını, imtiyaz süresinin otuz seneye indirilmesi durumunda vergi tarifelerini $C$ projesindeki tarifeyle aynı duruma getirmek zorunda kalacaklarını belirtmiştir. Ayrıca imtiyaz süresi sonunda şirketlerinin 18 milyon franklık tesis ve gelir bırakmış olacaklarını, fakat C projesinin yapacağı tesisin değerinin ise 10 milyon frank olacağını ileri sürmüştür. Son olarak Camus, hayvan kesiminden alınacak olan verginin Şehremaneti hesabına ve herhangi bir ücret talep etmeksizin kendileri tarafından tahsilini de kabullenmiştir. ${ }^{19}$

Neticede Camus'un tadilata göre yeniden hazırladığı sözleşme ve şartname projeleri Şehremanetine gönderilmiş ve prosedür gereği evraklar Vilâyet Meclis-i Umûmisi tarafından incelenerek Belediye Encümenine havale edilmiştir. 29 Ocak 1914 tarihinde Belediye Başkanı Cemil (Topuzlu) Beyle birlikte Nafia Encümen Reisi ve ayrica üç üyeden oluşan encümen tarafindan proje maddelerinin tertibi şeklen eksik görülerek yeniden düzenlenmiş ve imtiyaz hususunda ilerde bir problem çıkmaması için bazı değişiklikler yapılmıştır. Şehremanetinin hazırladığı sözleşmedeki İstanbul için sadece bir adet pazar yeri ile mezbaha yapılması teklifi mahzurlu görülmüştür. Gerekçe olarak İstanbul'un deniz kollarıyla ayrılması, yollardan ve nakliye vasıtalarından mahrum üç büyük bölgeye dağılması ve kalabalık olması vurgulanmıştır. Bu bağlamda Boğaziçi sahilleri ahalisinin et ihtiyaçlarının, özellikle de yaz mevsiminde Kazlıçeşme'den sevk olunacak et ile karşılanmasının zorluğu dile getirilmiştir. Kadıköy, Üsküdar ve Boğaz'ın Anadolu tarafının ihtiyacını karşılamak üzere o bölgede birkaç bölümden oluşan umumi bir pazar ve bir mezbahanın kurulmasının büyük kolaylık sağlayacağı düşünülmüştür. Fakat sonuç itibarıyla umûmi pazar ve mezbaha yapılmasındaki amaç kesimin sıhhi kontrolünün sağlanması olduğundan ve bunun ancak kesim mahallerinin azaltılmasıyla sağlanabileceğinden, imtiyazın verilmesi halinde diğer mezbahalar kapanıp sadece bir adet mezbaha kurulacağından ve mezbaha sayısının artmasının da harcanacak paranın bölünmesi anlamına geleceğinden Cemil Paşa'nın görüşleri doğrultusunda sadece bir mezbaha tesis edilmesi encümence uygun görülmüştür.

19 BOA, ŞD.851/22/35 Lef 2-3; 9 Teşrin-i evvel 1328 (22 Ekim 1912). 
Belediye Encümeninde ele alınan diğer bir husus, sözleşmenin ilgili maddesine göre imtiyaz bölgesine dışarıdan taze veya soğuk hava mahzenlerinde muhafaza edilmiş olarak et ve tuzlu etin getirilmemesidir. Bu madde, encümence ticaret anlaşmalarına aykırılığından ve ayrıca İstanbul'a ülkenin diğer vilâyetlerinden et ve kıyma, kavurma, pastırma, sucuk gibi müstahzaratların gelişinin de buna göre yasaklanıyor olmasından dolayı iptal edilmiştir. Ancak bu tür et ve et ürünlerinin Şehremaneti baytarları tarafından sıhhi muayeneden geçirilmesi kararlaştııılmış; kaçak et muamelesine tabi tutularak müsadere edilmesinin önüne geçebilmek için baytar muayenesinin ardından mezbahaya mahsus soğuk damga ile damgalanması uygun görülerek ilgili madde tadil edilmiş ve muhtemel et inhisarının önü alınmıştır.

Encümen ayrıca bazı vergi tarifeleri, bu tarifelerin uygulanması, vergilerin tahsil ediliş şekilleri ve sakatatların değerlendirilmesi gibi hususlarda yapılması gereken bir takım değişikliklerle ilgili görüşlerini beyan etmiştir. ${ }^{20}$

\section{5. İstanbul Valiliğinin Projeye Müdahalesi}

İmtiyaz talebiyle ilgili olarak Şehremaneti bir sözleşme ve bir de şartname düzenlemiştir. İstanbul Valiliği ise söz konusu evraklar üzerinde tadilata gitmiş ve Vilâyet Meclis-i Umûmisi Nafia Encümeni tarafından da birer sözleşme ve şartname hazırlanmıştır. Encümenin hazırladığı sözleşme ile Şehremanetinin hazırladığ1 sözleşmede birçok husus ortak olmasına rağmen Valiliğin, Şehremanetinin yetkilerine dair bazı konulara müdahale ederek karar mekanizmalarına katıldığı ve alınacak vergilerden kendisine de pay ayırdığ görülmektedir. Vilâyet Nafia Encümeninin hazırladığı sözleşmede yer alan bazı hususlar şöyle özetlenebilir:

Sözleşmeye göre imtiyaz sınırları, bir taraftan Rumeli Kavağı sahilinden Ayestafanos'a; öte yandan Anadolu Kavakları sahilinden Adalar dâhil Pendik'e kadar olan bölgeyi kapsamaktaydı. Valiliğin onayı ve resmi gazetede ilanından itibaren inşaat planları altı ay içinde Şehremanetine sunulacak olan sözleşme kırk yıl boyunca yürürlükte kalacaktı. Tesis, inşaat başlangıç tarihinden itibaren iki sene sonunda bitirilecek ve ardından Şehremanetinin oluşturacağ nun, tesisin anlaşma hükümlerine uygunluğuna dair raporu neticesinde kesin kabul işlemi yapılacaktı.

Sanayileşme faaliyetlerinin desteklenmesi bağlamında dönemin ruhuna uygun olarak mezbaha ve hayvan pazarı tesisi için de bazı kolaylıklar sağlanması düşünülmüştür. $\mathrm{Bu}$ nedenle tesisin inşası için sabit veya taşınır alet ve edevatla, taş, ahşap, maden vb. ülke içinden veya yabancı ülkelerden alınacak malzemele- 
rin bir defaya mahsus olarak gümrük vergisinden muaf tutulması hususu sözleşmeye konulmuştur. Öte yandan hayvanların tesise, karayolunun yanı sıra denizyolu ve demiryoluyla da getirilmesi şart koşulduğu için imtiyaz sahibi, mezbaha ve hayvan pazarında inşasına mecbur olduğu deniz iskelesinden başka tesisin şark demiryoluna bağlanmasını da üstlenecekti. ${ }^{21}$

Sözleşme, İstanbul'da usulsüz et kesimlerinin önüne geçebilmek için imtiyaz sahibine geniş yetkiler tanıyor, bu amaçla Şehremanetiyle sıkı bir işbirliğini öngörüyordu. Buna göre, kesilen hayvanlar, et çeşitleri ve sakatat damgalanacaktı. İmtiyaz sahibi ve görevlileri kasap dükkânlarını ve et satılan yerleri kontrol edebilecek, bu gibi ticaret yerleri birer defter tutacak, bu tür yerler açmak isteyenler imtiyaz sahibine bilgi vermek üzere Şehremanetine müracaata mecbur olacaklardı. Mezbaha görevlileri, zabıta refakatiyle dükkânları, sergileri, depo vb. mahalleri teftiş etme hakkına sahip olacakları gibi imtiyaz sınırları içinde arabaları, seyahat eden vapurları ve et muhafaza edilebilen kapları usul ve nizamına uygun şekilde kontrol edebileceklerdi. Sıhhi görevler belediye tarafından yerine getirilecekti. Hayvanların ve etlerin kontrolü için Şehremaneti, imtiyaz sahibiyle birlikte gereği kadar diplomalı baytar, baytar muavinleri ve müfettiş tayin edecek ve maaşları her sene başında imtiyaz sahibi tarafindan Şehremanetine ödenecekti.

İstanbul'un et sıkıntısı çekmemesi için imtiyaz sahibi, tarife gereğince hayvan sahiplerinden alacağ 1 vergiler karşı1lı̆̆nda, tüketime tahsis edilmiş olan hayvanların sağlıklarının korunmasını, beslenmesini, kesimini, et ve sakatatın hazırlanmasını ve zamanında bayilere gönderilmesini taahhüt ediyordu. Hizmetin aksamaması için günlük sarfiyata göre mezbahaların faaliyetleri için gereken araç ve gereçleri eksiksiz bir şekilde ve daima çalışır halde bulundurmak zorundaydı. ${ }^{22}$

Mezbaha ve hayvan pazarında verilen hizmetlerden ve tahsis edilecek mekânlardan alınacak vergilerin cins ve meblağları en ince detaylarına kadar tespit edilmiş ve sözleşmede yer almıştır. Söz konusu hizmetler ve vergi türleri kısaca şöyle özetlenebilir:

Pazara ve mezbahaya gelecek hayvanların baytar muayenesine tabi tutulması, muayeneden sonra pazara ve mezbahaya alınması, pazar ahırlarında sahibinin rızasıyla bir günden ziyade barındırılması, pazar mahalli mevkilerinin kullanılması, satılmayıp ahırlarda ve meydanlarda muhafaza edilen hayvanların tekrar pazara çıkışı, hayvanların kesilmeden önce otomatik sistemle tartılması,

21 BOA, ŞD.851/22/33 Lef 54-55, 9 Kanun-1 sani 1329 (22 Ocak 1914).

22 BOA, ŞD.851/22/33 Lef 56-57, 9 Kanun-1 sani 1329 (22 Ocak 1914). 
hayvanların kesimi ve etlerin hazırlanması, sakatatlarla işkembe, baş ve ayakların temizliği, hazırlanması ve boynuzların baştan ve tırnakların ayaktan ayrılmas1, derilerin tuzlanması, kesilen etlerin yine tartıldıktan sonra üzerine ağırlığını gösteren bir etiket yapıştırılması, yağların eritilmesi, sahiplerinin isteği üzerine etlerin soğuk hava mahzenlerinde korunması. Bunların dışında mezbahada ve pazar yerinde satılan etin ve canlı hayvanın satışı üzerinden yüzde bir buçuk vergi alınacaktı. Etin nakledileceği mahallerin uzaklığına ve nakliye şekline göre bir tarife hazırlanarak İstanbul Vilâyetine ve Şehremanetine onaylatılacaktı. Ayrıca kesilen etin mezbaha dâhilinde alenen satışı için imtiyaz sahibi tarafından satıcılara özel bir mekân tahsis edilecek, bu mekânların açılış-kapanış saatleri ve kullanım usullerine dair bir nizamname düzenlenecek ve Şehremanetince tasdik edilecekti. ${ }^{23}$

Sözleşmeye göre mezbahaya getirilen hayvanların barınma ve beslenme hizmetleri, masrafları karşılığında imtiyaz sahibine münhasır kılınmıştır. Hayvan sahiplerine ot, her çeşit yem ve hayvan yataklarının imtiyaz sahibinden satın alınması şart koşularak dışarıdan yem getirilmesi yasaklanmıştır. İmtiyaz sahibinin, hayvanların kesimi, nakliyatı, yem satışı ile diğer hizmetlerden ve nakdi cezalardan elde ettiği gelirlerden vereceği payın yanı sıra hayvan pazarına ve mezbahaya giren her hayvan için de valilik ve Şehremanetine belirli bir meblağ ödemesi kararlaştırılmıştır. ${ }^{24}$

Sözleşme, tesisin ve çalışanların kaza ve yangına karşı korunmalarına dair tedbirlerle ilgili hükümler de içermekteydi. Buna göre imtiyaz sahibi, tesislerin alet ve edevatı ile levazımını yangına karşı sigorta ettirecek, itfaiye teşkilatı ile araç gereçlerini temin edecek ve itfaiye personeline bir bina yapacaktı. Mezbaha ile pazar müstahdemleri de vazife esnasında uğrayacakları kazalara karşı sigorta edilecekti. ${ }^{25}$

Kırk yıl olarak tespit edilen sözleşme süresinin sonunda pazar mahalleri ve mezbahalar tüm binalarla birlikte alet, edevat ve sabit malzemeleri çalışır halde, hiçbir şekilde borç ve taahhütle ilişkisi olmayarak ve herhangi bir bedel talep etmeksizin Şehremanetine teslim edilecekti. Şehremaneti kesin kabul tarihinden itibaren, yirminci seneden sonra ne zaman isterse imtiyazın tamamını satın alma salahiyetine sahip olacaktı. İmtiyaz sahibi, tesisteki tüm faaliyetlerini valiliğin sözleşmeyi onayından itibaren altı ay içinde kurmak zorunda olduğu bir anonim şirketle yürütecekti. Ayrıca ilerde herhangi bir problemin çıkma ihtimaline karşın

23 BOA, ŞD.851/22/33 Lef 58-59, 9 Kanun-1 sani 1329 (22 Ocak 1914).

24 BOA, ŞD.851/22/33 Lef 60-61, 9 Kanun-1 sani 1329 (22 Ocak 1914).

25 BOA, ŞD.851/22/33 Lef 61-62, 9 Kanun-1 sani 1329 (22 Ocak 1914). 
imtiyaz sahibiyle, ittifakla ve usulüne uygun olarak sözleşmenin tadil edilebileceğine dair bir hüküm de konulmuştu. ${ }^{26}$

\section{6. İhalenin Yabancılara Verilmesine Celep Esnafinın İtirazı}

İhale süreci devam ederken Umûm Celep Esnafi Cemiyeti, mezbaha projesinin ecnebi bir şirkete verilmesinden duyduğu rahatsızlığı hem Meclis-i Mebûsan Başkanlığına, hem de İstanbul Vilâyeti Meclis-i Umûmi Başkanlığına yazılı olarak iletmiştir. Meclis-i Mebûsan Başkanlığına gönderilen arzuhalde cemiyet, bir yandan Osmanlılara ait olan bir işin ecnebilere kaptırılma tehlikesinden kurtarılmasının, diğer yandan İstanbul ve bilâd-1 selâsede* mezbaha tesis edilmesinin kesinlikle şart olduğunu ifade etmiştir. Haddi zatında cemiyet, mezbaha kurulmasının kasap ve celep esnafını, Şehremanetini ve halkın sağlı̆̆ını yakından ilgilendirmesi hasebiyle tüm şehir ahalisi tarafından arzu edildiğini bildirmektedir. Fakat cemiyete göre, şehrin büyüklügüü, ulaşım vasıtalarının azlığı, sokakların temizliği ve hava şartları göz önüne alındığında bir mezbaha ile ihtiyaçları görmek mümkün değildir. Ayrıca bu kadar büyük çapta bir mezbahanın inşası için gösterilen bütçe yeterli olamayacak ve Şehremaneti, yapılması düşünülen mezbahanın tahmini bütçesi olan on altı milyon frangı temin edemeyecektir. Öte yandan koyun sahiplerinin yeni mezbaha tarifesinde tespit edilmiş olan duhuliye*, zebhiye* ve diğer vergileri ödemeye güçlerinin yetmeyeceğini ve kasap esnafının, nakliye masraflarının üstesinden gelemeyeceğini ileri süren cemiyet, bu durumun et fiyatlarını da artırarak ahaliye yansıyacağını ve ahalinin et zammına tahammül edemeyeceğini iddia etmektedir.

Cemiyetin önerisi, şehrin büyüklüğü dikkate alınarak bir yerine altı tane fakat daha küçük çaplı, daha düşük maliyetli, nakliye masrafları hissedilmeyecek derecede az olan ve bizatihi Şehremanetinin inşa edebileceği mezbahalar tesis edilmesidir. İkinci bir öneri ise İstanbul'da umum celepler ile kasapların ve teşekkül eden şirketlerin birleşmesinden meydana gelecek bir anonim şirketin bu hizmetleri yerine getirmesidir. ${ }^{27}$

26 BOA, ŞD.851/22/33 Lef 63-64, 70, 9 Kanun-1 sani 1329 (22 Ocak 1914).

* Suriçi İstanbul'un dışında kalan Eyüp, Galata ve Üsküdar kazaları.

* Duhûliye: Bazı ticari eşyanın memlekete girişi esnasında alınan vergi. Şemseddin Sami, Kamus-ı Türkî, İstanbul, İkdam Matbaası, 1317, s. 603. Konumuz açısından ifade edecek olursak hayvanların mezbaha tesisine girişinde alınan vergi olarak nitelendirebiliriz.

* Zebhiye: Kasapların kestikleri hayvanlardan alınan vergi. Şemseddin Sami, a.e., s. 648.

27 BOA, ŞD.851/22/17 Lef 1,3, 28 Mayıs 1330 (10 Haziran 1914). 
Cemiyet daha sonra sözleşme şartlarının bazı maddelerini yorumlamakta ve eleştirmektedir. Sözleşmenin birinci maddesine göre şirketin imtiyaz alanı sur içi İstanbul ve bilâd-1 selâsenin yanı sıra Rumeli ve Anadolu Kavakları sahiline kadar Boğaziçi, Pendik, Ayastefanos ve Adalar kabul edilmiştir. Beşinci maddede de kışlalar, hastaneler ve her türlü müesseseler bu kapsama alınmıştır. Cemiyet söz konusu iki maddeyle bu bölgelerde bulunan devlete ait binaların ve askeri istihkâmlarla kışla, hastane ve her türlü müessesenin imtiyaz alanına girdiğini, böylece imtiyaz şirketi memurlarının kışla ve umum müesseseleri teftiş ve kontrol hakkı elde edeceğini ileri sürmüştür. Müteahhit tarafından askerlere verilecek koyunların ticari amaçlı olması nedeniyle kesimin yasaklanacağını ve ecnebi bir memurun askeri kurumları kontrolünün siyasi açıdan büyük sakıncalar taşıdığını ifade etmiştir.

Sözleşmenin, kasaplara defter tutmalarını ve teftiş edilmelerini getiren sekizinci maddesi de cemiyet tarafından eleştirilmişstir. Kasaplık yapanların \% 70 'inin Hıristiyan olduğunu belirten cemiyete göre millî uyanışın ortaya çıktığı böyle bir dönemde kasaplık inhisarının da ecnebilerin eline geçmesi, halkı Müslüman olan ülkenin, et gibi çok önemli bir erzakın teminini sağlayan celeplik ve kasaplık açısından mahvolması anlamına gelmektedir. Müslümanlar, şimendifer, reji, tramvay, düyûn-1 umûmiye ve banka gibi müesseselerin yönetiminde bulunmalarına rağmen yok hükmünde oldukları gibi ülkenin et ihtiyacını karşılayan mesleklerde de benzer bir durum ortaya çıkacaktır. Bu nedenle cemiyete göre mezbaha yapımı ve işletilmesi imtiyazının ecnebilere verilmesi kabul edilemezdir.

Cemiyet, on beşinci maddeye göre mezbahaya girdikten sonra bir günde kesilmeyen hayvanlar için hem barınma hem de yem parası alınmasının hayvan sahiplerine büyük zarar vereceğini düşünmektedir. Bu bağlamda, biraz zayıf olan veya baytar tarafından şüpheli raporu verilebilecek koyunun on gün veya daha fazla bekletilmesi halinde iaşe masrafları temin bedelini geçeceğinden celep zarar edecek ve imtiyaz sahibi kazanacaktır.

Cemiyete göre hayvanların İstanbul'a uzak bölgelerden nakli, nakliyat süresinin bazı nedenlerle uzayabilmesi, çok sayıda hayvanın aynı anda getirilerek bakımı ve kesilmesinin zaman almasından dolayı hayvanların uzun süre beslenmek zorunda kalmaları gibi zorlukların vergileri ve masrafları artırabilme ihtimalleri sözleşmede düşünülmemiştir. Cemiyet bu mahzurları şöyle ifade etmektedir:

Nakliye vasıtalarının azlığ 1 ve temin edilen bazı bölgelerin uzaklığı nedeniyle koyunun İstanbul'a getirilmesi uzun zaman alabilmektedir. Mesela Erzurum karamanlarının Trabzon iskelesinden İstanbul'a vapurla getirilmesi dört gün sürmekte; firtınalı havalarda ise bu süre on güne kadar çıkabilmektedir. Bir vapurda 
taşınan beş bin koyunun bir günde mezbahaya sevk olunması halinde tamamının aynı günde kesilmesi mümkün değildir. Fırtınadan dolayı bazen birçok telefatla çıkan koyunlar yürüyemez hale gelir. Bu koyunlar en az on gün hava almakla ve iyi beslenmekle kendisine gelebilir. $\mathrm{Bu}$ sebeple imtiyaz sahibinin ahırlarına kapatılacak hayvanların yirmi günden önce kesilmesi mümkün olamayacağından masraflara tahammül edemeyecek olan celep, koyunlarını bilâ bedel terk etmek zorunda kalacaktır. İzmir ve Bandırma iskelelerinden yüklenen hayvanlar bazı günlerde on binden fazlayı bulmaktadır. Sözleşmeye göre bu koyunların mezbahaya sevk edilmesi gerekmektedir. Ancak tamamı kesilemeyeceğinden ahırlara konulacak ve kokmuş kuru ot ile beslenecektir. Halbuki İzmir, Bandırma, Bergama, Karabiga, İzmit, Yalova, Karamürsel, Samsun, Giresun, Ereğli, Tekirdağ, Silivri, ve Çanakkale iskelelerinden vapurlarla gelen hayvanlar meralarda yeşil çimene alıştıklarından kuru ot yemezler. Normalde ortalama ağırlığı on beş okka gelen bir koyunun ağırlığı, son derecede aç olacakları zamanda on okkaya kadar düşecektir. Vilâyet encümen azaları bu konularda ihtisas sahibi olmadıkları için bu hususları düşünemeyerek sözleşmeyi hemen imzalamışlar ve ülke için büyük bir felakete neden olmuşlardır.

Cemiyetin eleştirilerinden biri de sözleşmeye göre hayvanları İstanbul dışında otlatma imkânlarının ellerinden alınma ihtimalidir. Cemiyetin ifadesine göre Konya, Ankara ve Sivas vilâyetlerinden temin edilerek senede dört yüz bini bulan beyaz karaman cinsi koyunlar sürülerle Uzun Çayır'a getirilir. Müşteri bulunması halinde müteahhitlere ve kasaplara satılır. Satılamayanlar ise etrafta bulunan boş meralarda otlatılır. Sözleşmenin uygulanması neticesinde bölge, imtiyaz sınırları içinde kalacağından şirketin elemanları, ticaret için getirildiği aşikâr olan bu hayvanları mezbaha ve umum pazar mahalline sevk edeceklerdir. Böylece haftalarca kuru ve kokmuş otu yiyemeyeceklerinden hem koyunların ağırlığı azalacak hem de büyük masraflardan dolayı celeplerin sermayesi yok olacaktır. Cemiyet, bu hususlar düşünülmediğinden, daha önce imzalanmış olmasına rağmen kendilerinin şikâyeti üzerine Vilâyet Meclis-i Umûmisinin oy çokluğuyla sözleşmeyi reddettiğini ifade etmektedir.

İstanbul'da umumi mezbahalara ihtiyaç olduğu halde hayvan pazarına gerek olmadığını iddia eden cemiyet Osmanlıdaki hayvancılıkla Avrupa'daki hayvancılık arasında karşılaştırma yapmıştır. Buna göre Osmanlı topraklarında genellikle koyun ve sığıılar meralarda otlatılmakta ve besi olarak yetiştirilmemektedir. Avrupa'da ise ziraat çok geliştiği ve boş araziler olmadığı için koyun ve sı̆̆̆rlar hara, ahır ve ağıllarda beslenmektedir. Bu nedenle umumi mezbaha kurulan yerlerde mutlaka umumi hayvan pazarları da kurulur. Çünkü her tarafı bahçe ve sayfiye yerler olduğundan sürülerle koyunların barınabileceği mahalleri bulunma- 
maktadır. Bu zaruretten dolayı hayvanları ihtiyaçlarına göre trenle veya vapurla umumi pazar yerlerine götürürler. İstanbul'da ise durum farklıdır. Gerek Üsküdar'dan Uzun Çayır'a, gerek Kasımpaşa'dan Okmeydanı'na kadar olan bölge ile Edirnekapı ve civarında elli-altmış bin koyun için boş meralar mevcut olup aynı zamanda uygun şekilde hayvan pazarları da kurulabilmekte ve şehre herhangi bir zararı bulunmamaktadır. Şehremaneti tarafından gereken düzenlemeler yapıldığ takdirde hem kontrol sağlanır hem de gece vakti veya belirli zamanlarda umumi mezbahalara hayvanlar nakledilebilir. Bu nedenle umumi mezbahalara ihtiyaç olmasına rağmen hayvan pazarlarına ihtiyaç yoktur. ${ }^{28}$

Arzuhalin son bölümünde cemiyet, Şehremaneti ile şirket arasındaki sözleşmenin imzalanması halinde pazar yeri vergisi, mezbaha ve nakliye ücreti ile iaşe masrafları nedeniyle etin fiyatı bir hayli artacağından, et taahhüdünden dolayı Harbiye Nezareti'nin yıllık yüz elli bin Osmanlı lirası kayba uğrayacağını ileri sürmektedir. Bunun yanı sıra cemiyetin hesabına göre şirketin mezbaha ve pazar yerinden kazanacağı paraya kıyasla Şehremanetine ödenecek para çok cüzi miktarda kalacaktır.

Cemiyet daha önce belirttiği İstanbul ve bilâd-1 selâsede altı adet mezbaha yapımı teklifini yinelemektedir. Cemiyetin talebi, mezbahaların Şehremaneti tarafından inşa ettirilmesi, masraflarına karşılık her koyun için belirli bir vergi alınmasıdır. Derinin temizlenmesi faaliyeti Yedikule'de bulunan debbağhanelerde tüccarlar tarafindan yerine getirilmeli ve mevcut fabrikalar kapanmamalıdır. Çünkü bu sayede devlet vergi ve temettu alır, işçiler para kazanır ve neticede milli iktisat ortaya çıkar. Hayvan pazarları zaten mevcut olduğu için ayrıca pazara gerek yoktur. Şayet Şehremanetinin selhâne inşasına gücü yetmezse planlar1nı, şartlarını, sürelerini belirlemek ve sadece Osmanlıları davet etmek koşuluyla kendisi bir müzayede yapabilir. Çünkü yalnızca Osmanlılardan müteşekkil cemiyetler, şirketler, umum celep esnafı ve kasapların birleşmesiyle istenilen şekilde selhâneler yapılması mümkündür. Yetkililerin talebi halinde, hükümetin idaresi altında bir anonim şirket kurulmalı fakat bütün faaliyetler ilgili Osmanlı esnafı tarafından yürütülmelidir. ${ }^{29}$

Umum Celep Esnafi Cemiyeti'nin ikinci arzuhal olarak İstanbul Vilâyeti Meclis-i Umûmi Riyasetine gönderdiği yazının girişinde de ihalenin, Osmanlı ticaretinin mahvı ve bir ecnebi kurumunun ihyasından başka bir anlam taşımadığ ifade edilmektedir. Daha sonra celeplerin kırsal alanlardan hayvan toplama süreçleri, hayvanların getirilmesi ve sevkiyatı esnasında çekilen zorluklar, bu faaliyet-

28 BOA, ŞD.851/22/17 Lef 3,5, 28 Mayıs 1330 (10 Haziran 1914).

29 BOA, ŞD.851/22/17 Lef 7, 28 Mayıs 1330 (10 Haziran 1914). 
ler vasıtasıyla binlerce insanın maişetini kazandığ 1 ve ilgili vergilerin ödendiği dile getirilmektedir. Ayrıca Şehremanetinin celepler tarafından ihtikâr yapıldığ 1 iddiası kesin bir şekilde reddedilerek bunun imkân dâhilinde bile olmadığı ileri sürülmektedir.

Diğer yazıda ele aldığı mahzurlara tekrar dikkat çeken cemiyet, İstanbul'a bir günde giriş yapan yirmi bin hayvanın tamamının kısa sürede kesilemeyeceğinden bahisle hayvanların mezbaha ahırlarında kalması nedeniyle esnafin masraflarını karşılayamayacağını, taze samana alışmış olan hayvanların kuru ot yiyemeyeceği için \%30 civarında zayıflayacağını, bu durumun celebin iflası ve şirketin ihyası anlamına geleceğini belirtmektedir. Arzuhale göre yirmi bin hayvanın on bini İzmit ve Trabzon'dan İstanbul'a denizyoluyla nakledilmektedir. Bandırma'dan da günlük iki-üç vapurla beş-altı bin hayvan getirilmekte, bir o kadarının sevkiyatı da karayoluyla yapılmaktadır. Bu kadar çok sayıda hayvanın mezbaha ve ahır masraflarının fiyatlara yansıyarak bunun sıkıntısını ahalinin çekeceği, et ihtiyacını celep ve kasap müteahhitler karşıladığı için askeriyenin iaşe masraflarının da artacağı, Şehremanetinin gelirlerinin kısmen çoğalmasına karşılık askeriyenin daha fazla zarar edeceği vurgulanmaktadır.

Cemiyetin iddiasına göre mezbaha kurulduktan sonra hayvanlar düşük fiyata satın alınmak istenecek ve celepler ucuz fiyata satmak zorunda kaldıklarında da Şehremaneti, daha önce fiyatların celeplerin ihtikârından dolayı yükseldiğini söyleyecektir. Halbuki bu durumda ticaret serbestisi ortadan kalkacak ve celepler sürekli zarara tahammül edemeyeceğinden İstanbul'a mal getirmeyeceklerdir.

Cemiyetin hatalı gördüğü hususlardan biri de sözleşmenin, bir kuzunun ağırlığının altı okkadan fazla gelmesi durumunda koyun rüsumuna tabi tutulacağını bildiren maddesidir. Cemiyet, Anadolu'dan gelen kuzuların on okkadan aşağı olmadığını ve sözleşmenin uygulanması durumunda kuzuların altı okkaya ulaşmadan pazarda satılacağını beyanla bundan dolayı ülkedeki koyun cinsinin varl1ğının tehlikeye düşeceği konusundaki endişelerini paylaşmıştır.

Mezbahaların inşasına karşı çıkmadıklarını bilakis ciddi şekilde desteklediklerini bu arzuhalinde de tekrarlayan cemiyet, İstanbul ve bilâd-1 selâsede sekiz adet mezbahaya ihtiyaç duyulduğunu ifade etmektedir. Bu sekiz mezbaha deniz üzerinde kurulabileceğinden hem sıhhi olacağ 1 , hem de eski şehreminlerinden Reşid Paşa'nın kararlaştırdığ nabileceği ileri sürülmektedir. Buna mukabil pazar yapımına karşı çıkan cemiyet zaten otlak olarak kullanılan Okmeydanı ve Uzun Çayır'ın hayvan pazarı olarak da düzenlenebileceğini savunmuştur. Cemiyetin önerisine göre Şehremaneti tarafından 1slah edilerek bu iki bölgede muntazam bir şekilde pazar kurulabilecek- 
tir. Bu sayede kontrol altına alınacak pazardan vergi de toplanabilecektir. Celep esnafı böylece imtiyaz sahibinin inisiyatifine bırakmadan hayvanlarını kendileri besleyebilecektir. Ayrıca hayvanların yemleri çoğunlukla Osmanlılardan meydana gelen arpacı ve uncu esnafindan satın alınarak bu iki esnafın ayakta kalması sağlanacaktır. Netice itibarıla hem millet bir ecnebinin ihtikârından kurtulacak hem de ahali eti ucuza alabilecektir. Ayrıca Şehremaneti elli bin liradan fazla bir gelir elde edebilecektir.

Cemiyet, yazının sonunda böyle bir sözleşmenin bir iki gün zarfindaki müzakere neticesinde kabulünün ülke için telafisi imkânsız bir zarar doğuracağını, bu nedenle konunun önemine dikkat çekmek için yazıyı gönderdiklerini, yıllık üç milyon tutarındaki bir alış-verişin bir ecnebinin ihtikârına bırakılamayacağını ifade etmiştir. ${ }^{30}$

\section{7. İmtiyaz Kararının İptali Ve Emile Camus'un Protestosu}

Şehremanetinin kurduğu komisyonun yaptığı inceleme ve değerlendirmeler sonucunda Emile Camus'un sahibi olduğu proje birinci olmasına rağmen kendisine imtiyaz hakkı verilmemiştir. Kendisinden istenilen tadilatın bir iki istisnası dışında diğerlerini yerine getireceğini bildirmesi sonucu değiştirmemiştir. Projenin iptal nedenlerinden biri Belediye Cemiyet-i Umûmisinin feshedilmesi ve icra vekillerinin oluşmamasıdır. Bu nedenle sözleşme ve şartnameyle birlikte vergi tarifesi evrakları Şûra-yı Devlet'e gönderilmiştir. İkinci neden Şehremaneti ile İstanbul Valiliği arasındaki yetki karmaşası, daha doğrusu valiliğin, Vilâyet İdare Kanunu'nun 78. maddesine dayanarak 40 yılı aşmamak üzere talep edilen imtiyazları verme yetkisinin kendilerinde olduğunu iddia etmesidir. Üçüncü neden ise Vilâyet Meclisi'nin şartnameyi yetersiz ve kendi içinde çelişkili bulmasıdır.

İmtiyazın yürürlüğe girmeyerek sürüncemede kalması ve kendisine verilmemesi üzerine proje sahibi Emile Camus, Fransa Sefareti vasıtasıyla Şehremanetine resmi bir protesto göndermiştir. Söz konusu protestoda, ihale tamamen sonuçlandığ ve komisyon projesini birinci seçtiği için tesisi kurma ve işletme hakkını kazandığını, bu nedenle projesinin uygulamaya konulması gerektiğini iddia ederek ihale sürecini ve bu süreçte yaptığı hazırlıkları anlatmıştır.

Camus, münakasa* yoluyla gerçekleşen proje yarışmasının sonucu ilan edilir edilmez, en yeni ve en mükemmel selhâneler inşası için daha önce yapılan müsabakalarda birçok başarı göstermiş olan şehir mimarı Jules Bilitch başkanlığında

30 BOA, ŞD.851/22/26 Lef 2-3, 21 Kanun-1 sani 1329 (3 Şubat 1914).

Alınacak veya yaptırılacak bir şeyin en az bedele razı olana ihale olunmak üzere müsabakata konması. Şemseddin Sami, a.e., s. 1409. 
mühendislerden ve mimarlardan oluşan bir komisyonu İstanbul'a gönderdiğini, ayrıca başka bir komisyon daha oluşturduğunu belirtmektedir. Ekibinin birkaç ay çalıştıktan sonra çok mükemmel bir dosya düzenlediğini ve bu faaliyetlerin birkaç yüz bin franka mal olduğunu ileri süren Camus, münakasa için belirlenen 2-15 Mayıs 1911 tarihinde 10.000 Osmanlı lirası kefalet akçesini yatırmış, fenni ve mali yeterlik belgeleriyle birlikte dosyasını Şehremanetine teslim etmiştir. $\mathrm{Bu}$ esnada Şehremininin değişmesi ve Şehremanetinin hizmetinde muktedir mühendisler bulunmaması nedeniyle komisyon tarafindan projelerin incelenmesi hususu gecikmiştir. İhaleye katılan tüm proje dosyalarının incelenmesine ancak sekiz ay sonra başlanabilmiş, bunun için Şehremaneti, bir komisyon kurulmuştur. Altı kişiden oluşan komisyon dört ay boyunca projeleri inceledikten sonra 1 Mayıs 1912 tarihinde raporunu tamamlayarak Camus'un projesinin, tüketim ve ihtiyaçları karş1layabilmesi, en yeni ve en mükemmel selhânelerin özelliklerini taşıması ve hayvan pazarı ile selhâne ücret tarifesinin rakiplerinden daha uygun bulunmasından övgüyle söz etmiş; onun projesini en yüksek; diğerlerini ise vasat ve en düşük olarak değerlendirmiştir. Şehremaneti diğer katılımcıların projeleri ile kefalet akçelerini kendilerine iadeyle sadece Camus'un proje ve kefalet akçesini alıkoymuştur. Belediye Meclis-i Umûmisi 18 Ekim 1912 tarihli toplantısında komisyonun kararını onaylamış buna karşılık sözleşmenin bazı maddelerin tadilini istemiştir. Camus bu karar üzerine gereken tadilatı yapmayı ve 50.000 Osmanlı lirası aidat vermeyi kabullenmiştir.

Camus protesto mektubunda bildirdiğine göre, o dönemde çıkarılan yeni kanun gereği, sözleşme ile şartnamenin tasdiki için İstanbul Vilâyeti Meclis-i Umûmisinin toplanmasını beklemiştir. Fakat Vilâyet Meclisi 4 Şubat 1912 tarihli toplantısında, imtiyaz için verilen belediye onayının, Şehremanetinin hazırladığ 1 münakasa şartnamesinin yetersiz olduğu ve Şehremanetiyle birlikte Camus'un belirlediği hususların şartnameye aykırı bulunduğu gerekçesiyle geçersiz kılınmasına karar vermiştir. ${ }^{31}$ Şehremanetinin yeni bir şartname düzenledikten sonra tekrar bir münakasa ihalesi yapacağına dair duyumlar aldığını ileri süren Camus, projesinin talepleri karşılayabilmesine rağmen imtiyazın iptalinin caiz olamayacağını, hukuken sahip olduğu müktesep hakları için ihtiraz kayıtlarını yazılı olarak ilettiğini, tadilatları kabulünün rakiplerine fesih talebi için bir hak doğurmayacağını beyan etmiştir. Buna gerekçe olarak da diğer projelerin eksikliklerini öne sürmüştür. ${ }^{32}$ 
Camus, protesto mektubunun sonunda, imtiyaz alabilmek için yaptığı masrafları gündeme getirmiştir. Buna göre imtiyaz sahibi olarak verdiği kefalet parasını gözden çıkardığını, bunu karşılayabilmek için bankaya ödediği komisyonların ve diğer masrafların çok büyük olduğunu ve halen bu paranın Şehremanetince alıkonulduğunu, işin yapılması için gereken 18 milyon frank sermayeyi hazırlamasına rağmen geçen sürenin zarar etmesine sebebiyet verdiğini zikretmiştir. Öte yandan İstanbul'daki vekillerine ve avukatlarına çok fazla ücret ödediğini belirterek imtiyazın iptali durumunda, projeyi hazırlamada çektiği sıkıntılardan ve meydana gelen üç milyon frank zarardan Şehremanetini sorumlu tutacağını bildirmiştir. $^{33}$

\section{Projenin Sonuçsuz Kalması ve Hükümetin Protestoya Karşı Tavrı}

Konuyla ilgili belgelerden anlaşıldığına göre uzun bir süre proje ve imtiyaza dair herhangi bir işlem yapılmamıştır. Bunda muhtemelen I. Dünya Savaşı'nın araya girmesi önemli bir etkendir. Şehremini Cemil Bey, 11 Aralık 1919 tarihinde Dâhiliye Nezaretine gönderdiği bir yazıda proje sürecinde yaşananları tekrar gündeme getirmiştir. Cemil Bey’in ifadelerine göre Şehremaneti, 17 Eylül 1912 tarihinde E projesiyle ilgili sözleşme ve şartnamelerin yanı sıra daha önce belirlenen vergi tarifesini, o esnada Belediye Cemiyeti Umûmisi feshedilip icra vekili oluşmadığı için Şûra-yı Devlete göndermiştir. Şûra-yı Devlet de ilgili evrakları valiliğin talebi ve Vilâyet Meclisinin toplantı tarihinin yaklaşması nedeniyle valiliğe sevk etmiştir. Vilâyet Meclisi toplantısında bu gibi imtiyazların şartlarının belirlenmesinin kendilerine ait olduğu, Şehremanetince düzenlenen müsabaka programının yetersiz bulunduğu ve E projesinin komisyon tarafından birinci seçilmesinin proje sahibine müktesep hak vermeyeceği yönünde karar alınmıştır. $\mathrm{Bu}$ nedenle şehre ahali için daha faydalı ve her türlü ihtiyacı karşılamaya yetecek şekilde bir mezbaha tesisi için ayrıca bir şartname düzenlenmesi ve ihaleye çıkılmadan önce bu evrakların incelenmesi amaciyla Vilâyet Umûm Meclisi'ne gönderilmesi gerektiği ifade edilmiştir.

Şehremaneti encümenindeki görüşmelerden çıkan sonuç ise Vilâyet Meclis-i Umûmisinin bu kararının Şehremanetinin yetkilerine karşı olduğu ve ihtilafın Şûra-yı Devlet tarafından halledilmesinin gerekliliği yönündedir. Ayrıca proje sahibinin vekili P. Andonyadis Efendi'nin, Emil Camus adına gönderdiği protestoya karşılık Şehremaneti Hukuk İşleri Müdürlüğü tarafından gönderilen yazıda resmi işlemlerin tehirinin Şehremanetinin yetkisi dışındaki nedenlerden kaynaklandığ 1 için zarar ve ziyana muhatap olamayacağ 1 beyan edilmiştir. Müdürlük, 
bunun yanı sıra henüz sözleşmenin imza ve teatisi yapılmadığ için mezbahanın Şehremaneti tarafından inşası ve işletilmesi veya mali sıkıntılar sebebiyle bunun gerçekleşmemesi halinde daha çok fayda sağlanabilecek yeni bir şartname hazırlayarak imtiyaz vermeye yetkili olup olamayacakları hususunda Şûra-yı Devletten bilgi istemiştir.

Şûra-yı Devlet Maliye ve Nafia dairesinin 23 Mayıs 1915 tarihli mazbatasında Vilâyat İdare Kanunu'nun 78. maddesinin, söz konusu imtiyaz yetkisinin vilâyete ait olduğuna dair bir açıklık içermediği, Dersaadet Belediye Kanunu'nun 3. maddesine göre mezbaha inşa ve tesisi yetkisinin Şehremanetine aidiyetinin gayet sarih olduğu belirtilmiştir. Şûra-yı Devlet buna ilave olarak imtiyaz hakk1nın, evrakların ilgili birimlerce imzalanmasından ve meclisten geçerek padişaha arz edilmesinden sonra kesinlik kazanacağını, bu işlemler gerçekleşmediği için ortada fesih ve iptale konu olacak bir hakkın mevcut olmadığını bildirmiştir.

Şûra-yı Devletin görüşlerine istinaden Şehremaneti Encümenindeki müzakerelerde mezbaha inşası imtiyazının verilmesine Şehremanetin yetkili olduğunun net bir şekilde ortaya koyulduğu ifade edilmiştir. Şehremaneti Encümeni, ekseriyetle projenin fesih ve iptaline ve harp sonrasında ihtiyaca göre ne kadar mezbaha ve hayvan pazarı yapılması gerekiyorsa ona göre projelerin düzenlenip hazırlanmasına dair iznin alınması için meselenin Belediye Cemiyet-i Umûmisine sunulmasının uygun olacağına karar vermiştir. Bu amaçla Şehremini Bedri Bey'e gönderilen evraklar, daha sonra memuriyeti gereği Haleb'e tayin edildiğinde istenmesine rağmen Bedri Bey kendisinde bulunmadığını söylemiş; Belediye Umum Cemiyeti de konuyla ilgili bilgilendirilmediği için mesele sürüncemede kalmıştır.

Cemil Bey tekrar Şehremini olduğunda mevcut mezbahaları eskisinden daha kötü halde bulduğunu ve bu ihtiyacın acilen halledilmesi gerektiğini belirterek $\mathrm{E}$ projesinde gösterilen mükemmel bir mezbaha inşasının en az 5-6 senede tamamlanacağını ve maliyetinin 5-6 milyon lira tutacağını ileri sürmüştür. Cemil Bey, sıhhi ve fenni bir-iki mezbaha yapılmasını elzem ve öncelikli gördüğünden Anadolu tarafında Selimiye mezbahasının askeriyeden kiralanmasını ve İstanbul'a çok uzak mesafedeki Erenköy, Beykoz, Sarıer, Bakırköy ve Adalar'da sıhhi kaidelere uygun mezbahalar kurulmasını önermiştir. İstanbul ve Beyoğlu'nun ihtiyaçları için, yedi ayda tamamlanmak üzere Karaağaç’taki (Sütlüce) eski tersane mahalline yapımı düşünülen yeni bir mezbahanın ihalesi, münakasada en uygun fiyatı teklif eden Manizade Hacı Hüseyin Efendi'ye verilmiştir. Cemil Bey, Karaağaç'da mezbaha inşasının geçici mahiyette görüldüğünü, bunun ayrıca mevcut ve gelecekteki ihtiyacı karşılayacak fenni ve terakkiye uygun büyük ve mükem- 
mel bir mezbahanın tesisine engel olmadığını, ayrıca Karaağaç’ta tesis edilecek mezbahanın E projesi sahibinin hukukuna taarruz anlamına gelmediğini ifade etmiştir. ${ }^{34}$

Emil Camus'un protestosuna müdahil olan Hariciye Nezareti, Şûra-yı Devletin görüşüne paralel olarak projenin Şehremaneti tarafindan inceleme, tadil ve kabulüyle ilgili dairelere iadesi, Meclis-i Vekâletin tasdiki ve padişahın onayının ardından yürürlüğe girebileceğini ve ancak ondan sonra bir müktesep hakkın söz konusu olabileceğini yinelemiştir. Zira Hariciyeye göre ilgili prosedürlerin tamamlanmaması durumunda cari uygulamaya göre hiçbir imtiyazın verilmesi mümkün değildir. Öte yandan proje, fenni komisyonun muvafakatını kayıtsız şartsız elde edememiştir. Komisyonun muvafakatı tamamen yok sayılsa bile yine de bundan dolayı bir müktesep hak kazanılamayacağı aşikârdır.

Hariciye Nezareti, imtiyazın yanı sıra hasılattan Şehremanetine düşecek hisse gibi konularda da ihtilafin ortaya çıktığına söyleyerek müteahhit ile Şehremaneti arasında bu konuda bir uzlaşmanın mevcudiyetine dair Şûra-yı Devletin veya Meclis-i Vükelânın onayına sunulan bir durumun söz konusu olmadığını, bu nedenle müteahhidin, kendisine imtiyaz veren herhangi bir müktesep hakka sahip bulunmadığını beyan etmiştir. Bundan böyle Camus'un zarar ve ziyan veya mevcut olmayan imtiyaz ve hukukunun tasdikini isteme imkânı kalmamıştır. Hariciye Nezaretinin öne sürdüğü argümanlardan biri de Şehremaneti ile İstanbul Valiliği arasında selhânelerin münakasa yoluyla inşası hususunda ortaya çıkan ihtilaftır. Bu ihtilafa binaen Şûra-yı Devletin 24 Mayıs 1915 tarihli kararına göre E projesinin haiz olabileceği üstünlük, ihale ilanı şartlarına göre tahakkuk etmemiştir. Ayrıca savaş sırasında düşman addedilen Türkiye ile ilişki kurmalarının imkânsızlığının yanı sıra önceden hazırlanmış olan tarifelerin yeniden incelenmesi talebiyle müteahhidin oluşturduğu komisyonun kendisi de bu durumu adeta itiraf etmiştir. Buna binaen padişahın onayına sunulsa bile tekliflerini uygulayamayacakları için zarar ve ziyan talepleri mümkün değildir.

Hariciye Nezareti, tüm delillerin Camus'un haksız olduğunu ortaya koyduğunu düşünmesine rağmen sessiz kalmanın, protestonun kabullenildiği şeklinde yoruma yol açmaması için gereken cevabın verilmesi gerektiğini vurgulamıştır. Öte yandan usule ilişkin yapılan bir hataya da değinen Hariciye Nezareti, çekilen protestonun resmi olarak protesto hükmüne giremeyeceğini, çünkü protestonun ancak Osmanlı adli kâtibi marifetiyle tebliğ edilebildiğini ve Fransa Fevkalade Komiserliği vasıtasıyla gönderilemeyeceği hususunun verilecek cevapta işlen- 
mesi gerektiğini belirtmiştir. Hariciye Nezaretine göre proje sahibiyle icra ve tevdi edilen evraklardan anlaşıldığına göre Şehremaneti'nin yapması gereken iş, evrakları Belediye Cemiyet-i Umûmisinin incelemesine göndermektir. ${ }^{35}$

\section{Sonuç}

19. yüzyılın sonlarında İstanbul'da fenni ve modern bir mezbahanın kurulması zaruri hale gelmiştir. Her ne kadar şehrin bazı yerlerinde faaliyet gösteren mezbahalar mevcut idiyse de buralarda canlı hayvanların ve etlerin muntazam ve sıhhatli bir şekilde kontrolünün yapılamadığ 1 yetkili makamlarca ifade edilmiştir. Böyle bir tesisin kurulmak istenmesinin genel olarak nedenleri, mevcut mezbahaların ve kesim usullerinin sağlığa zararlı olması, şehirde çirkin koku yayması ve başkent İstanbul'a yakışmayacak şekilde kötü bir görüntü vermesi, kontrolün tam olarak sağlanamaması nedeniyle ihtikâra, dolayısıyla fiyat artışlarına yol açması ve Şehremanetinin gelirlerini artırma çabasıdır.

Şehremaneti bu nedenlerle çağın gereklerine uygun, fenni, sshhi ve umumun faydalanabileceği büyük bir mezbaha ve hayvan pazarı tesisi için 1911 yılında bir proje müsabakası düzenlemiştir. Teslim edilen projeleri incelemek ve en uygun olanı seçmek üzere ilgili kurumlardan uzmanların bir araya getirilmesiyle bir komisyon teşkil edilmiştir. Komisyon, öncelikle Almanya ve Fransa gibi gelişmiş ülkelerde konuya dair literatürü incelemiş ve mükemmel bir mezbaha ve hayvan pazarında bulunması gereken özelliklere ilişkin görüşlerini içeren bir rapor hazırlamıştır. İhale, kapalı zarf usulü münakasa yoluyla yapılmıştır. Harflerle sembolize edilen altı projeden ikisi ön şartları yerine getirmediği ve tam olarak anlaşılamadığ 1 için değerlendirmeye tabi tutulmadan elenmiştir. Projelere 10 üzerinden not verilmiş; komisyondaki altı üyeden dördü Emile Camus'a ait olan ve E harfiyle sembolize edilen projeyi diğerlerinden açık ara ile birinci seçmiştir. Buna istinaden bir mezbaha, hayvan pazarı ve ilgili bina ve tesisleri kurarak kırk yıllığına işletmesi için proje sahibine imtiyaz verilmesi kararlaştırılmıştır. İki üye $\mathrm{E}$ ve $\mathrm{C}$ projelerinin diğerlerinden üstün olduğuna katılmakla birlikte her iki projenin de beklentileri tam olarak karşılamadığını ve bunlardan hiç birinin sözleşmede tadilat yapılmaksızın kabul edilemeyeceğini belirtmiştir. Bu nedenle İstanbul'un ihtiyaçlarının ve Şehremanetinin menfaatlerinin dikkate alınması ve bu amaçla $\mathrm{E}$ ve $\mathrm{C}$ projelerinin birleştirilerek yeni bir proje hazırlanmasının daha uygun olacağı yönünde görüş bildirmişlerdir.

Emil Camus, projede tadilat yapmayı kabul etmesine rağmen ortaya çıkan bazı problemlerden dolayı kendisine imtiyaz verilmemiş, netice itibarıla mez- 
baha ve hayvan pazarı projesi akamete uğramıştır. İmtiyazın verilmeme nedenlerinden biri komisyonda tüm üyelerin ittifakıyla karar alınmamasıdır. Diğer bir neden, o dönemde belediyede meydana gelen yönetim değişikliklerinden dolay1 projenin onay süresinin uzamasıdır. Önemli bir neden de imtiyaz ihalesi konusunda Şehremaneti ile İstanbul Valiliği arasında ortaya çıkan yetki karmaşasıdır. Valiliğin, vilâyet kanununa göre imtiyaz verme yetkisinin kendisinde olduğuna dair 1srarına rağmen Şehremaneti, belediye kanununa göre kendilerinin yetkili olduğunu iddia etmiştir. Ayrıca Vilâyet Umûm Meclisi, Şehremaneti ve Camus tarafından hazırlanan sözleşme ve şartnamelerin bazı maddelerini uygun bulmayarak değişiklik yapmış ve hem sürece hem de gelirlerin paylaşımına dâhil olmuştur. İmtiyaz yetkisi tartışması Şûra-yı Devlet'e intikal etmiş ve Şehremaneti lehine karar çıkmışsa da imtiyazın uygulanması konusunda bir ilerleme kaydedilmemiştir. Böylece İstanbul'da modern bir mezbaha ve hayvan pazarı tesis etme çabaları, kısaca ifade etmek gerekirse o dönemde bu tür faaliyetler esnasında sıkça karşılaşılan bürokratik engeller, mevzuattan kaynaklanan karmaşalar ve kısır çekişmeler nedeniyle sürüncemede kalarak sonuca ulaşamamıştır.

Camus, projede kendisinden istenen tadilatı kabul etmesine rağmen imtiyazın iptal edilmesinden dolayı Şehremanetine protesto göndermiş ve zarar ettiği gerekçesiyle tazminat talebinde bulunmuştur. Osmanlı hükümeti, komisyondan Camus'un projesi lehine karar çıkmasına rağmen gerekli imzalar atılmadığı, bundan dolayı proje imtiyazı resmi olarak yürürlüğe girmediği için herhangi bir feshin ve müktesep hakkın, dolayısıyla da tazminat talebinin söz konusu olamayacağını belirterek protestonun geçersiz olduğunu ilan etmiştir. Şehremaneti imtiyazın iptal edilmesi üzerine İstanbul'un mezbaha ihtiyaçları için farklı arayışlara gitmiştir. Bir yandan Anadolu yakası için bazı bölgelerde mezbahalar kurulması önerilmiş; öte yandan Beyoğlu ve İstanbul'un ihtiyaçlarını karşılamak amacıyla günümüzde daha çok Sütlüce olarak bilinen Karaağaç mevkiinde bir mezbaha yapılması kararlaştırılmıştır. Yedi ayda tamamlanması öngörülen mezbaha tesisi, en uygun fiyatı veren Manizade Hacı Hüseyin Efendi'ye 1919 yılında ihale edilmiştir. 


\section{Kaynakça}

\section{Arşiv Kaynakları}

Başkanlık Osmanlı Arşivleri (BOA), İstanbul.

DH.MKT.926/57/1 Lef 1, 9 Kanun-1 sani 1320 ( 22 Ocak 1905).

DH.MKT. 926/57/5 Lef 2, 14 Mart 1321 (27 Mart 1905).

DH.UMVM.83/26/1 Lef 1, 9 Ağustos 1332 (22 Ağustos 1916).

DH.UMVM.98/11/1 Lef 1, 3, 4, 11 Kanun-1 evvel 1335 (11 Aral1k 1919).

ŞD.851/22/17 Lef 1, 3, 5, 7, 28 Mayıs 1330 (10 Haziran 1914).

ŞD.851/22/26 Lef 2, 3, 21 Kanun-1 sani 1329 (3 Şubat 1914).

ŞD.851/22/32 Lef 2, 3, 4 Eylül 1329 (17 Eylül 1913).

ŞD.851/22/33 Lef 3, 4, 5, 11 Kanun-1 sani 1329 (24 Ocak 1914); Lef 11, 13, 14, 15, 27, 28, 29, 35, 16 Nisan 1328 (29 Nisan 1912); Lef 54, 55, 56, 57, 58, 59, 60, 61, 62, 63, 64, 68, 69, 70, 9 Kanun-1 sani 1329 (22 Ocak 1914).

ŞD.851/22/35 Lef 2, 3, 9 Teşrin-i evvel 1328 (22 Ekim 1912).

ŞD.851/22/36 Lef 2, 16 Nisan 1328 (29 Nisan 1912).

ŞD.2827/1 Lef 2, 3, 4, 5, 7 Şubat 1914.

Y.PRK.AZJ.19/42/1 Lef 1, 3, 3 Haziran 1307 (15 Haziran 1891).

\section{Kitaplar ve Makaleler}

Aydın, Mehmet, "Mütareke Döneminde İstanbul Basınında Karaağaç Mezbahası'na Yönelik Tartışmalar”, Uluslararası Sosyal Araştırmalar Dergisi, volume 3, issue 14, Fall 2010.

Doğru, Halime, "Rumeli’de Celepkeşanlar",

http://docs.neu.edu.tr/library/nadir_eserler_el_yazmalari/Dergiler/1_Belletenler/1502.pdf, Erişim tarihi 14.04.2020.

Öztel, Muharrem, "Tanzimat Dönemi ve Sonrasında İstanbul Et Piyasasını Düzenlemek İçin Alınan Tedbirler”, History Studies, volume 5, issue, 5, Eylül/ September 2013.

Şemseddin Sami, Kamus-ı Türki, İstanbul, İkdam Matbaası, 1317.

Tabakoğlu, Ahmet, "Osmanlı Döneminde İstanbul'un İaşesi”,

/29mayis/1519/AHMET\%20TABAKO\%c4\%9eLU.pdf?sequence=1\&isAllowed=y, Erişim tarihi 14.04.2020. 
Tuncer, Seral, "II. Meşrutiyet Döneminde Bir İdari Reform: 1913 İdare-i Umûmiye-i Vilâyat Kanun-1 Muvakkatı", http://cdn.istanbul.edu.tr/FileHandler2.ashx? $\mathrm{f}=$ ii.-mesrutiyet-doneminde-bir-idari-reform-1913-idare-i-umumiye-i-vil\%C3\%A2y\%C3\%A2t-kanun-i-muvakkati_seral-tuncer.pdf,, Erişim tarihi 29.05.2020.

Uğur, Sinem Burcu - Tan, Seda, "19.Yüzy1l Mezbaha Reformu ve Osmanlı'daki Yansımaları”, MAE Veterinerlik Fakültesi Dergisi, 4 (1), 2019.

Uzun, Ahmet, Istanbul'un İaşesinde Devletin Rolü: Ondalık Ağnam Uygulaması 1783-1857, Ankara, Türk Tarih Kurumu Yayınları, 2006. 